\title{
OPTIMIZATION AND CHARACTERIZATION OF FORMULATION SELF-NANOEMULSIFYING DRUG DELIVERY SYSTEM ETHANOL EXTRACT OF ROMANG PARANG LEAVES (BOEHMERIA VIRGATA)
}

\author{
MAGFIRAH*, INDAH KURNIA UTAMI \\ Department of Pharmacy, College of Pharmaceutical Sciences Pelita Mas Palu, Central Sulawesi 94111, Indonesia. \\ Email: magfiralukman@gmail.com
}

Received: 08 October 2020, Revised and Accepted: 10 November 2020

\begin{abstract}
Objective: Parang romang (Boehmeria virgata) is one of the traditional medicines that are used empirically by Makassar tribal healers, South Sulawesi, as an antitumor drug. This traditional medicine contains secondary metabolites such as alkaloids, flavonoids, tannins, and saponins. However, secondary metabolites of those leaves extract have low solubility in water. Hence, to be formula, self-nanoemulsifying drug delivery system (SNEDDS) is one of the solutions to increase the extract solubility.

Methods: The optimization of two formula optimum SNEDDS parang romang leaves (T80PGMZ and T20PGMZ) was using the simple lattice design (SLD) method which will give 28 SNEDDS formula parang romang leaves each of which the formula is tested for its characteristics as a critical point include emulsification time, \% transmittance, drug loading, particle size, zeta potential, polydispersity index, and morphology particle.
\end{abstract}

Results: The results of SNEDDS characterization obtained the optimum formula T80PGMZ with emulsification time $12.6 \mathrm{~s}$, \% transmittance 92.21\%, drug loading $0.068 \mathrm{mg} / \mathrm{ml}$, particle size $370.26 \mathrm{~nm}$, zeta potential $-31.4 \mathrm{mV}$, polydispersity index of 0.615 , and regular particle morphology with spherical chunks at a magnification of 10.000 times with a particle size of $10 \mu \mathrm{m}$.

Conclusion: SNEDDS of parang romang leaves extracts that used olive oil as oil phase, Tween 80 as a surfactant, and propylene glycol as the cosurfactant provided nanoemulsion with good characteristics.

Keywords: Optimization, Characterization, Self-nanoemulsifying drug delivery system, Ethanol extract of parang romang leaves.

(c) 2021 The Authors. Published by Innovare Academic Sciences Pvt Ltd. This is an open access article under the CC BY license (http://creativecommons.org/ licenses/by/4.0/) DOI: http://dx.doi.org/10.22159/ajpcr.2021v14i1.39922. Journal homepage: https://innovareacademics.in/journals/index.php/ajpcr

\section{INTRODUCTION}

The use of herbal extracts has various limitations such as instability, metabolism by the liver, toxic effects on other cells, and poor water solubility so that the drug levels in the blood are below the therapeutic concentration which results in low or no therapeutic effect [1]. It is necessary to develop methods to improve the delivery of herbal medicines used in diseases such as cancer and viral infections, considering that the discovery of new drugs is currently dominated by drugs with poor solubility resulting in low levels. Various methods are used to improve the solubility of these drugs, one of which is a nanoemulsion that can deliver drugs at specific targets which can reduce toxicity and side effects at non-target sites. One of the most researched drug delivery systems currently is the SNEEDS [2]

SNEDDS has been widely developed to increase the solubility and availability of lipophilic drugs including glipizide [3-5]. However, the use of SNEDDS preparations for the development of native Indonesian medicinal plant formulations in herbal dosage forms is rarely reported.. The leaves of parang romang (Boehmeria virgata) have been used by Makassar tribe healers as antitumor, scientific research on the ethanol extract of parang romang has an IC value of $9.40 \mu \mathrm{g} / \mathrm{ml}$ and has selective cytotoxicity properties against several cancer cell lines, namely, HeLa, T47D, and Vero cell lines [6]. This study aims to develop a SNEDDS preparation for the ethanol extract of parang romang leaves to obtain the optimum formula using the simple lattice design method. The formula obtained is then characterized to produce the best quality.

\section{MATERIALS AND METHODS}

Materials

Materials were used in this research include 96\% ethanol (Sigma), Tween 80 (Brataco), Tween 20 (Brataco), propylene glycol (Brataco), PEG 400 (Brataco), olive oil (Bertolli) artificial gastric fluid, and artificial intestinal fluid which consists of sodium chloride (Merck), hydrochloric acid (Merck), potassium hydrogen phosphate (Merck), sodium hydroxide (Merck), and distilled water.

\section{Extraction}

Simplicia powder parang romang leaves were extracted using the maceration method. Maceration was done by soaking $800 \mathrm{~g}$ of powder simplicia in $6 \mathrm{~L}$ of ethanol $96 \%$ for $5 \times 24 \mathrm{~h}$. The filtrate was evaporated at $60^{\circ} \mathrm{C}$ to obtain the concentrated extract.

\section{Preparation of SNEDDS}

SNEDDS was prepared by mixing ethanol extract, parang romang leaves $50 \mathrm{mg}$ are added to $5 \mathrm{ml}$ of the carrier component which is T80PGMZ (Tween 80, PG, and olive oil), and T20PGMZ (Tween 20, PG, and olive oil). The formulation homogenized with a magnetic stirrer hotplate at $45^{\circ} \mathrm{C}$ for $30 \mathrm{~min}$. The percentage was used to determine the lower limit and upper limit, as shown in Table 1.

The results of the mixing were kept $24 \mathrm{~h}$ at room temperature to see homogeneity. Optimized and characterized formulas include emulsification time, \% transmittance, drug loading, particle size, zeta potential, polydispersity index, and morphology particle. 
Optimization of SNEDSS

Emulsification time

Each formulation was dropped wise added to $5 \mathrm{ml}$ distilled water at $37^{\circ} \mathrm{C}$ in a magnetic stirrer at $120 \mathrm{rpm}$. The formed emulsion was visually observed [7].

\section{$\%$ Transmittance}

A total of $100 \mu \mathrm{L}$ of SNEDDS formula were added with distilled water up to $50 \mathrm{~mL}$ in the vortex for $30 \mathrm{~s}$. \% transmittance was measure by spectrophotometry at a wavelength of $650 \mathrm{~nm}$ with a distilled water blank to determine the level of clarity [8].

\section{Drug loading}

A total of $5 \mathrm{ml}$ of SNEDDS formula were centrifuged at $3500 \mathrm{rpm}$ for $10 \mathrm{~min}$. The supernatant was taken and then diluted with $5 \mathrm{ml}$ of ethanol, add to the ethanol until $10 \mathrm{ml}$. Then analyzed by spectrophotometry at a length of $650 \mathrm{~nm}$. The drug loading is calculated by the following equation:

$$
\text { Drugloading }=\frac{\text { Theamount of drug trapped }}{\text { Thetotalamount of drug }} \times 100
$$

Table 1: Percentage of upper and lower limits of SNEDDS components

\begin{tabular}{lll}
\hline Component & The lower limit (\%) & The upper limit (\%) \\
\hline Tween 80 & 65 & 67 \\
Tween 20 & 65 & 67 \\
PG & 30 & 32 \\
Olive oil & 3 & 5 \\
\hline
\end{tabular}

SNEDDS: Self-nanoemulsifying drug delivery system

\section{Characterization of SNEDDS}

Particle size, polydispersity index, and zeta potential

The particle size, polydispersity index, and zeta potential of the nanoemulsion observed by particle size analyzer (PSA) (Horiba Scientific SZ-100, Horiba, Kyoto, Japan). A total of two drops of nanoemulsion were mixed into $5 \mathrm{~mL}$ of distilled water, $3 \mathrm{~mL}$ of it was taken and put into a cuvette for analysis.

Scanning electron microscope (SEM)

The morphology of the nanoemulsion particles observed by SEM.

\section{RESULTS AND DISCUSSION}

Result

Extraction

The resulted extract by maceration of $800 \mathrm{~g}$, the percentage yield of maceration was $5.31 \%$.

\section{Preparation of SNEDDS}

The optimization results of surfactant, cosurfactant, and oil composition using a simple lattice design method, three variation formulas are obtained 28 formulas. The results of optimization from surfactant and cosurfactant compositions are shown in Table 2.

\section{Emulsification time}

The results of the optimization of the emulsification time of SNEDDS ethanol extract of parang romang leaves use the simple lattice design are shown in Table 2 .

\section{Percent of transmittance}

In this study, the percent transmittance test was carried out by spectrophotometry at a wavelength of $650 \mathrm{~nm}$ and aquadest as blank. The optimization percent of transmittance results are shown in Table 2.

Table 2. Optimization SNEDDS formulation of the ethanol extract of Parang Romang leaves

\begin{tabular}{|c|c|c|c|c|c|c|c|c|}
\hline \multirow[t]{2}{*}{ No } & \multicolumn{4}{|c|}{ Composition Formula } & \multirow[t]{2}{*}{ Homogen } & \multicolumn{3}{|c|}{ Optimasi formula } \\
\hline & Tween $80(\%)$ & Tween $20(\%)$ & PG (\%) & Olive oil (\%) & & $\begin{array}{l}\text { Emulsification } \\
\text { Time (s) }\end{array}$ & Transmiitance (\%) & $\begin{array}{l}\text { Drug loading } \\
(\mathrm{mg} / \mathrm{ml})\end{array}$ \\
\hline 2 & 66.33334 & - & 30.33333 & 3.333326 & $\sqrt{ }$ & 15 & 36.6463 & 0.0411121 \\
\hline 3 & 65.33334 & - & 31.33333 & 3.333326 & $\sqrt{ }$ & 14 & 42.3753 & 0.0291495 \\
\hline 4 & 67 & - & 30 & 3 & $\sqrt{ }$ & 13 & 91.1998 & 0.0650374 \\
\hline 5 & 66 & - & 31 & 3 & $\sqrt{ }$ & 15 & 61.4654 & 0.0264393 \\
\hline 6 & 65 & - & 30 & 5 & $\sqrt{ }$ & 14 & 40.8476 & 0.0212056 \\
\hline 7 & 65 & - & 31 & 4 & $\sqrt{ }$ & 14 & 37.055 & 0.0830841 \\
\hline 8 & 65 & - & 32 & 3 & $\sqrt{ }$ & 15 & 55.8835 & 0.0174673 \\
\hline 9 & 65 & - & 32 & 3 & $\sqrt{ }$ & 16 & 43.8563 & 0.0355981 \\
\hline 10 & 65 & - & 30 & 5 & $\sqrt{ }$ & 15 & 40.3736 & 0.0313925 \\
\hline 11 & 65.66666 & - & 30.66667 & 3.666674 & $\sqrt{ }$ & 15 & 43.9369 & 0.0375607 \\
\hline 12 & 66 & - & 30 & 4 & $\sqrt{ }$ & 13 & 52.8844 & 0.0621402 \\
\hline 13 & 66 & - & 31 & 3 & $\sqrt{ }$ & 14 & 49.7403 & 0.0332617 \\
\hline 14 & 65.33334 & - & 30.33333 & 4.333326 & $\sqrt{ }$ & 14 & 59.245 & 0.0971028 \\
\hline 16 & - & 66.33334 & 30.33333 & 3.333326 & $\sqrt{ }$ & 14 & 50.4334 & 0.0306449 \\
\hline 17 & - & 65.33334 & 31.33333 & 3.333326 & $\sqrt{ }$ & 16 & 58.2586 & 0.0355981 \\
\hline 18 & - & 67 & 30 & 3 & $\sqrt{ }$ & 14 & 86.9661 & 0.0520467 \\
\hline 19 & - & 66 & 31 & 3 & $\sqrt{ }$ & 14 & 55.3709 & 0.0395421 \\
\hline 20 & - & 65 & 30 & 5 & $\sqrt{ }$ & 14 & 55.1282 & 0.0384953 \\
\hline 21 & - & 65 & 31 & 4 & $\sqrt{ }$ & 16 & 49.5486 & 0.0349439 \\
\hline 22 & - & 65 & 32 & 3 & $\sqrt{ }$ & 17 & 43.9616 & 0.0317664 \\
\hline 23 & - & 65 & 32 & 3 & $\sqrt{ }$ & 16 & 44.3749 & 0.0318972 \\
\hline 24 & - & 65 & 30 & 5 & $\sqrt{ }$ & 17 & 40.937 & 0.0186822 \\
\hline 25 & - & 65.66666 & 30.66667 & 3.666674 & $\sqrt{ }$ & 17 & 41.0693 & 0.0293364 \\
\hline 26 & - & 66 & 30 & 4 & $\sqrt{ }$ & 18 & 45.7816 & 0.0134486 \\
\hline 27 & - & 66 & 31 & 3 & $\sqrt{ }$ & 16 & 41.4106 & 0.015972 \\
\hline 28 & - & 65.33334 & 30.33333 & 4.333326 & $\sqrt{ }$ & 14 & 60.8864 & 0.0349439 \\
\hline
\end{tabular}


Drug loading

In this study, the drug loading SNEDDS of the ethanol extract of parang romang leaves by spectrophotometry at a wavelength of $650 \mathrm{~nm}$. The optimization of drug loading results are shown in Table 2.

Determination of the optimum formula for SNEDDS ethanol extract of parang romang leaves

Selection and determination of the optimum formulation SNEDDS of ethanol extract parang romang leaves are homogeneity, emulsification time, percent transmittance, and drug loading by expert design 12 simplex lattice design method. The results are shown in Table 3.

Particle size, indeks polidipersitas, and zeta potential

The particle size, index polydispersity aims to determine the size range of SNEDSS by Particle Size Analyzer (PSA)[9]. Characterization of SNEDSS formulation for zeta potential by Particle size analyzer (PSA) aims to provide an overview of the stability of formula over a long period [10]. The results of particle size, polydispersity index, and zeta potential of each formula can be seen in Table 4 .

Scanning Electron Microscopy
The results morphology of the SNEDSS ethanol extract parang romang leaves with a magnification of 10,000 times with a particle size of $10 \mu \mathrm{l}$ can be seen in Fig. 4.

\section{DISCUSSION}

The SNEDDSs are mixtures are oil, surfactants, cosurfactants, and also an active drug compound that will produce oil-in-water $(\mathrm{o} / \mathrm{w})$ emulsion into aqueous media by mild agitation [11]. SNEDDS formulation of the extracts increases the bioavailability of the extract, so the effectiveness of therapy is improved [8]. The leaves of parang romang (B. virgata) have been used by Makassar tribe healers as cancer [6]. However, Extract ethanol parang romang its low oral bioavailability. To increase the bioavailability of the ethanol extract of parang romang leaves is to make SNEEDS.

In this study, the SNEDDS preparation was designed by a simple lattice design which is 28 formulas. The formulation optimization to select the levels of the variables (the amount surfactant, cosurfactant, and oil) from which product has the best quality such as homogeneity, emulsification time, \% transmittance, and drug loading. The selected and characterization formulation optimal was based on the homogeneity (no phase separation), minimizing the emulsification time, maximizing $\%$

Table 3. Result Optimization SNEDDS formulation of the ethanol extract of Parang Romang leaves

\begin{tabular}{|c|c|c|c|c|c|c|c|c|}
\hline \multirow[t]{2}{*}{ Nama formula } & \multicolumn{5}{|c|}{ Komposisi formula } & \multicolumn{3}{|c|}{$\begin{array}{l}\text { Characterization of the SNEDDS Formula of Parang Romang } \\
\text { Leaf Ethanol Extract }\end{array}$} \\
\hline & $\begin{array}{l}\text { Tween } \\
80(\%)\end{array}$ & $\begin{array}{l}\text { Tween } \\
20(\%)\end{array}$ & $\begin{array}{l}\text { Tween } \\
20 / 80(\%)\end{array}$ & PG (\%) & $\begin{array}{l}\text { Olive } \\
\text { oil (\%) }\end{array}$ & $\begin{array}{l}\text { Emulsification } \\
\text { Time (s) } \pm S D\end{array}$ & $\begin{array}{l}\text { Transmittan } \\
(\%) \pm S D\end{array}$ & $\begin{array}{l}\text { Drug loading } \\
(\mathrm{mg} / \mathrm{ml}) \pm \mathrm{SD}\end{array}$ \\
\hline$A$ & $80 \%$ & - & - & 10 & 10 & $12.608 \pm 1.06$ & $92.218 \pm 8.13$ & $0.068 \pm 0.08$ \\
\hline $\mathrm{B}$ & - & 75 & - & 15 & 10 & $14.091 \pm 1.25$ & $75.131 \pm 3.89$ & $0.039 \pm 0.04$ \\
\hline
\end{tabular}

Table 4. Results of particle size and polydispersity index and zeta potential

\begin{tabular}{lllll}
\hline \multirow{2}{*}{ Nama formula } & \multirow{2}{*}{ Komposisi formula } & \multicolumn{2}{l}{ Characterization of the SNEDDS Formula of Parang Romang Leaf Ethanol Extract } \\
\cline { 3 - 5 } & & Particle size \pm SD (nm) & Indeks Polidipersitas \pm SD & Zeta Potensial \pm SD(mV) \\
\hline Formula A & T80PGMZ & $370.26 \pm 11.49$ & $0.607 \pm 0.38$ & $-31.4 \pm 0.54$ \\
Formula B & T20PGMZ & $397.23 \pm 7.25$ & $0.732 \pm 0.81$ & $-29.7 \pm 0.26$ \\
\hline
\end{tabular}

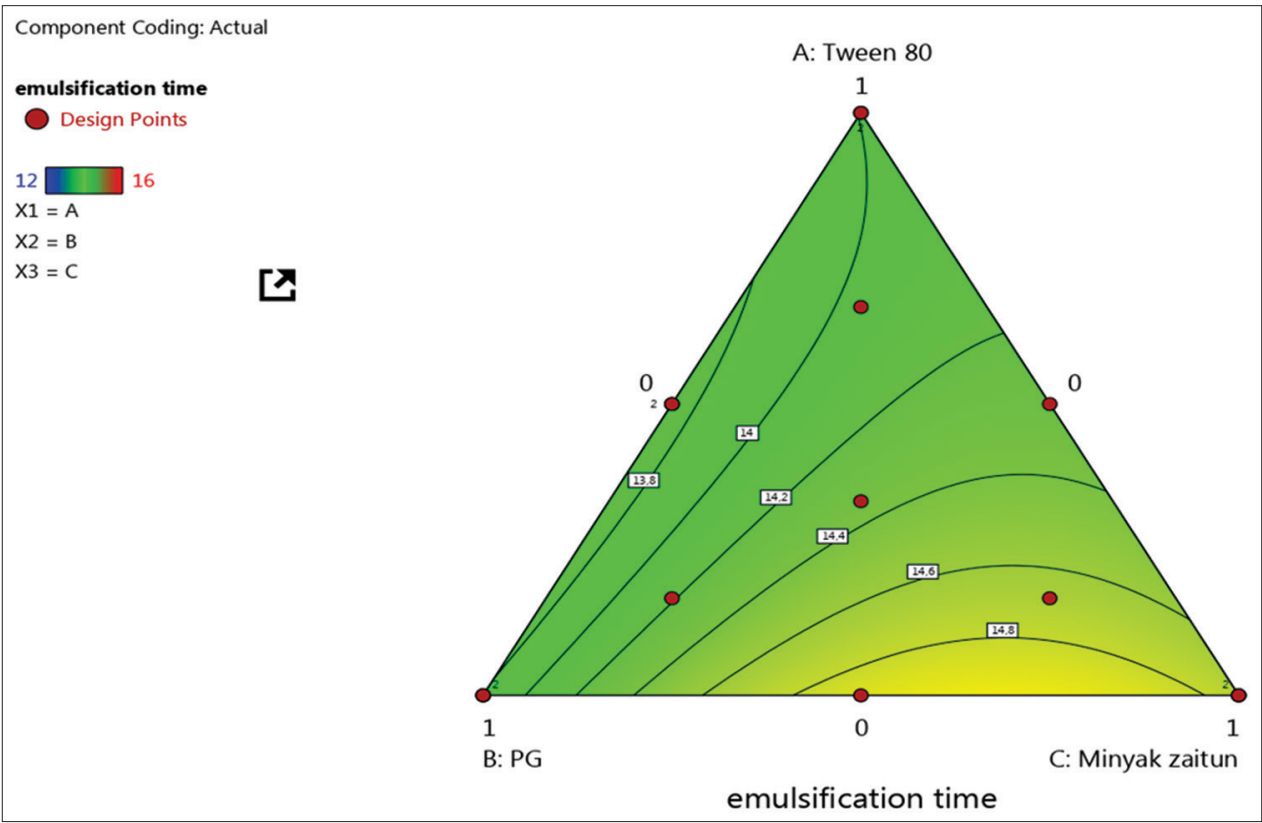

Fig. 1: Contour plot emulsification time formula T80PGMZ 
transmittance [7], and maximizing drug loading, minimizing the droplet size, index polydispersity, and maximizing zeta potential.

Emulsification time was known as a great importance parameter to describe the stability of the system and prepare emulsification in the gastric fluid of SNEDDS self-emulsifying characteristics [7]. All formula SNEDDS ethanol extract parang romang (1-28) have shown spontaneity of emulsification $<1$ min and good stability without any signs of extract or excipient precipitation. Tween 80 and Tween 20 are a non-ionic surfactant with low toxicity, better emulsification ability that allowed rapid dispersion when in contact with biological fluids [7], hydrophilelipophile balance value of 15 which can reduce the interface tension between oil and water so that it can help speed up the emulsification time [12]. The value of emulsification time was illustrated by colors that follow the spectrum of light [13]. The high emulsification time value is indicated by increasingly close to blue. As shown in Fig. 2, the time required for emulsification increased the concentration of Propilenglycol (PG). PG commonly use in nanoemulsion formulation to increase the mixing of water and oil due to partition between the two phases.

Percent of transmittance was used to observe the self-emulsification process by measuring the transmittance of the solution during dissolution as the emulsification process happened [7]. Table 2 shows composition 1, 4 (T80PGMZ) 92,1147\%, 91,1998\% and 15 (T20PGMZ) 87,407\%, $86,9661 \%$ have clear dispersion with almost $100 \%$ clarity, indicating fulfillment of the nanoemulsion requirement [14]. As shown in Fig. 3, the required for $\%$ transmittance increased concentration of Tween 80/Tween 20. High surfactant concentration followed by cosurfactant and olive oil concentration produces a percent transmittance approaching 100\% because the surfactant has lipophilic and hydrophilic parts which can reduce the interface stress so that it affects the nanoemulsion formation process, as well as the nanoemulsion droplet size [15]. The value of the transmittance was illustrated by colors that follow the spectrum of light [13]. The higher transmittance value indicated more to red.

Drug loading aims to evaluate drug entrapment in the SNEDDS [16]. If the levels are higher, it is expected that the drug can reach target cells in the body without being influenced by enzymes in the digestive tract because SNEDDS can bind and protect drugs from the first-pass metabolism [17]. Table 2 shows composition 1, 4 (T80PGMZ) $0.068215 \mathrm{mg} / \mathrm{ml} ; 0.06503$ $\mathrm{mg} / \mathrm{ml}$; and 0.01518 . (T20PGMZ) $0.05659 \mathrm{mg} / \mathrm{ml}, 0.05204 \mathrm{mg} / \mathrm{ml}$ have maximizing drug entrapment, indicating fulfillment of the nanoemulsion requirement [16]. As shown in Fig. 4, the required for drug loading increased concentration of Tween 80/Tween 20. High surfactant concentration, low concentrations of olive oil produce a large drug loading, this is because surfactants have lipophilic and hydrophilic parts which function to reduce interface stress and have a major effect on the nanoemulsion formation process, as well as the size of the nanoemulsion droplets and cosurfactant amphiphilic compounds, have an affinity to water and oil to reduce interface stress, increase interface fluidity, and increase the mixing of water and oil due to the partition between the two phases to increase the drug loading SNEDDS [15]. The value of the transmittance was illustrated by colors that follow the spectrum of light [13]. The higher transmittance value indicated more to red. Based on Table 2 , the recommended optimum formulas T80PGMZ1 and formula T20PGMZ15 were 67\% Tween 80/ Tween $20,30 \%$ PG, and $3 \%$ oil with desirability each $0,0.846$, and 0.981 . Result optimization SNEDDS formulation of the ethanol extract of parang romang leaves is shown in Table 3.

The particle size, Polydispersity-Index (PI), and zeta potential aim to determine the size range and stability of SNEDSS by PSA [16]. Based on Table 4, the particle size, PI, and zeta of the selected formulation were found to be T80PGMZ $(370,26 ; 0,607$; and -31,4) and T20PGMZ $(397,23 ; 0,732$; and $-29,7)$. All formulas have to minimize the droplet size, index polydispersity, and maximizing zeta potential. The droplet size of SNEDDS ethanol parang romang ranges 370.26-397.23 and size SNEDDS approximately $\leq 600 \mathrm{~nm}$ [18], Normally, the mean globule size is about $100-500 \mathrm{~nm}$ and present mainly as water-in-oil and o/w [19-23]. The smaller the droplet size of the nanoemulsion, the larger the surface area provided for drug absorption [19] and particle size was impacted by increased concentration of surfactant as at higher concentration, the amount of surfactant was sufficient to cover primary emulsion [22]. The globule size determines the extent and rate of drug release as well as absorption and improves the bioavailability of SNEDSS [7]. The PI of SNEDDS parang romang 0.607 and 0.732 indicating that the system had narrow size distribution, homogeneity of the droplet in the formulation [7]. A lower PI value near zero indicates monodisperse droplet size, where a PI value closer to one indicates a wide range droplet size [20]. The significance of zeta potential value could be related to the stability

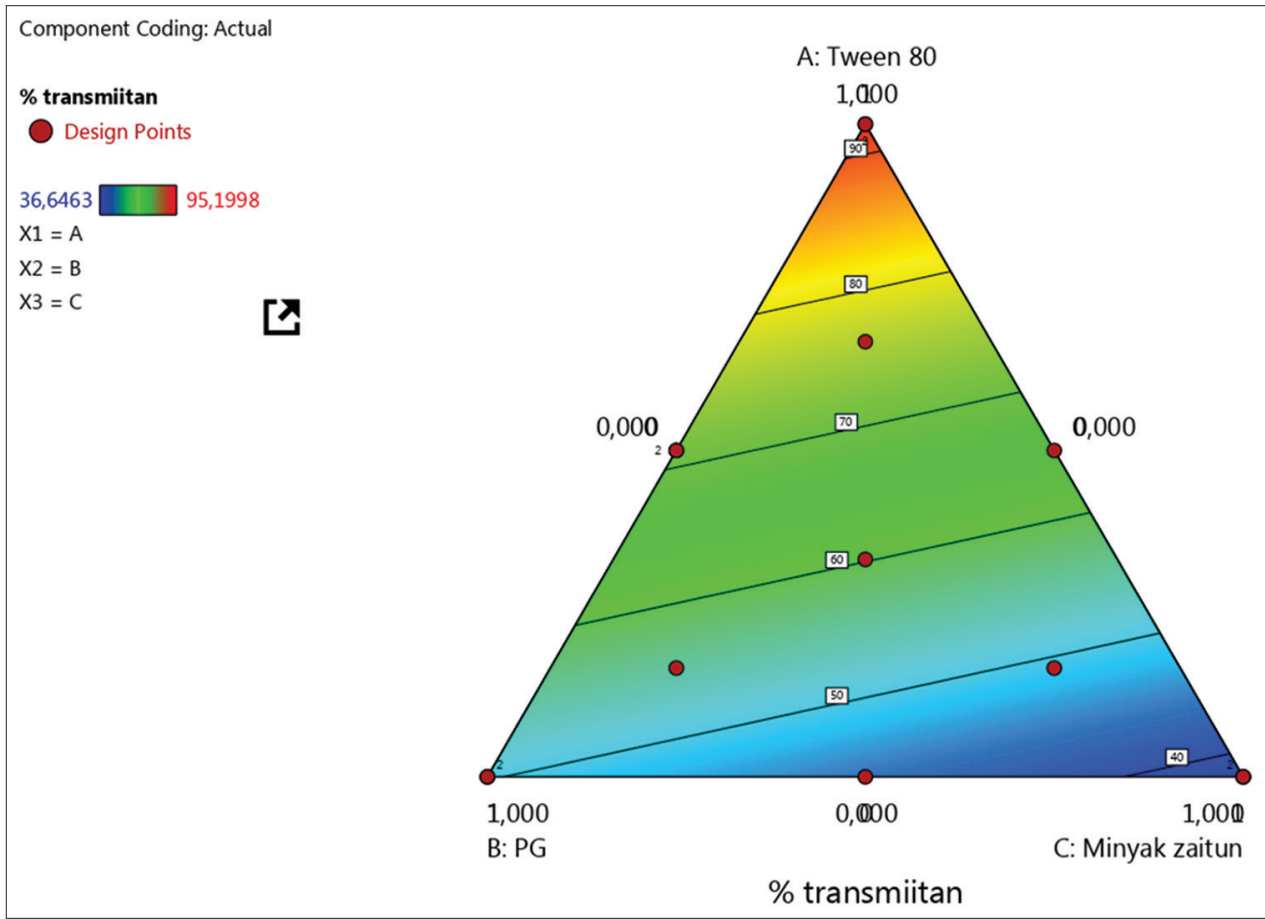

Fig. 2: Contour plot emulsification time formula T80PGMZ 


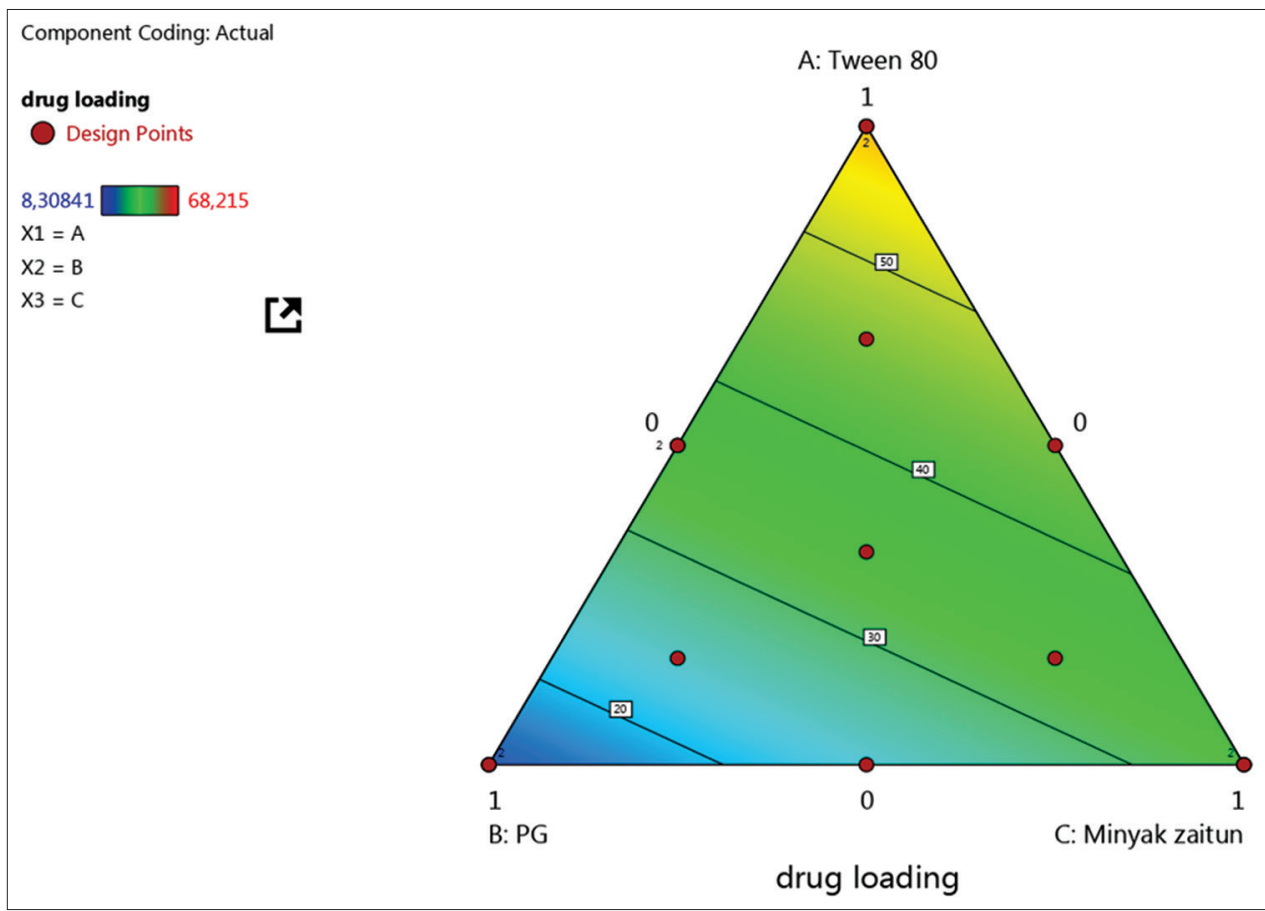

Fig. 3: Contour plot \% transmittance T80PGMZ

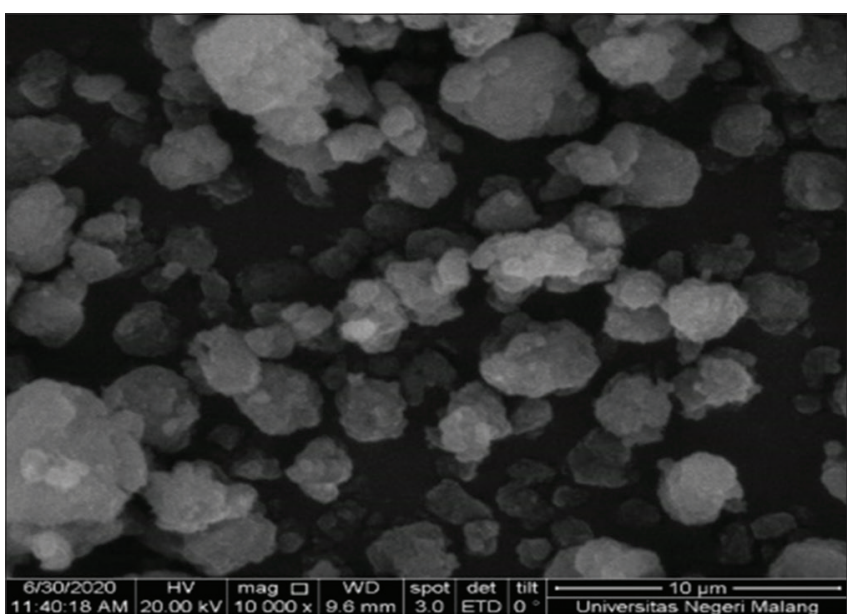

Fig. 4: Scanning electron microscopy formula T80PGMZ

of colloidal dispersions. Colloids with high zeta potential (negative or positive) are electrically stabilized and vice versa [19]. The zeta potential of SNEDDS ethanol parang romang is negative in both formulations which are -31.4 and -29.7 . Zeta potential requirements for nanoemulsion preparations are $>+30 \mathrm{mv}$ and $>-30 \mathrm{mv}$ [21]. The positive result shows that particles are dispersed in a positive charge and vice versa [19].

Particle morphological observation aims to determine the shape and size of the particles of each SNEDDS formulation using scanning electron microscopy [20]. The results of the morphology of the SNEDSS formula for ethanol extract parang romang leaves with a magnification of 10,000 times with a particle size of $10 \mu \mathrm{l}$ are shown in Fig. 1. From the observations, it can be seen that the morphological shape of the SNEDDS particle size is in the form of chunks that have a spherical shape, but those that have a regular spherical shape are formula T80PGMZ. The formula is consisting of a mixture of ethanol extract of parang romang leaves, olive oil, Tween 80 , and propylene glycol.

\section{CONCLUSION}

SNEDDS of parang romang leaves extracts that used olive oil as oil phase, Tween 80 as a surfactant, and propylene glycol as the cosurfactant provided nanoemulsion with good characteristics. The characterization is the emulsification time value of $12.6 \mathrm{~s}$, percent transmittance $92.21 \%$, drug loading $68.21 \mathrm{ppm}$, particle size $370.26 \mathrm{~nm}$, polydispersity index 0.607 , zeta potential $-31.4 \mathrm{mV}$, and particle morphology with spherical chunks at a magnification of 10,000 times with a particle size of $10 \mu \mathrm{m}$.

\section{CONFLICTS OF INTEREST}

There are no conflicts of interest among the authors.

\section{CONTRIBUTION OF AUTHORS'}

All authors have contributed equally to the research work.

\section{FUNDING}

This research was supported by the Ministry of Research, Technology, and Higher Education (Ristekdikti).

\section{ACKNOWLEDGMENTS}

The author expresses my deep thanks to the Ministry of Research, Technology, and Higher Education (Ristekdikti) for providing the opportunity to conduct and finance this research.

\section{REFERENCES}

1. Chaturvedi M, Sinhal A, Kumar M, Saifi A. Recent development in novel drug delivery systems of herbal drugs. Int $J$ Green Pharm 2011;5:87-94.

2. Krishnaiah YS. Pharmaceutical technologies for enhancing oral bioavailability of poorly soluble drugs. $J$ Bioequivalence Bioavailab 2013;2:29-36.

3. Dash RN, Mohammed H, Humaira T, Ramesh D. Design, optimization and evaluation of glipizide solid self-nano emulsifying drug delivery for enhanced solubility and dissolution. Saudi Pharm J 2015;23:528-40.

4. Fahmy UA, Ahmed OA, Hosny KM. Development and evaluation of avanafil self-nano emulsifying drug delivery system with rapid onset of action and enhanced bioavailability. AAPS PharmSciTech 2015;16: 
53-8.

5. Kamble RN, Mehta PP, Kumar A. Efavirenz self-nano-emulsifying drug delivery system: In vitro and in vivo evaluation. AAPS PharmSciTech 2016;17:1240-7.

6. Manggau M, Andriani F, Nurdin WB, Yulianti R, Sutriadi S. In vitro study of the alkaloid anticancer compound from Makassar medicinal plants Boehmeria virgata Linn. Int J Pharm Sci Rev Res 2018;13:77-81.

7. Ujilestari T, Martien R, Ariyadi B. Self-nano emulsifying drug delivery system (SNEDDS) of Amomum compactum essential oil: Design, formulation, and characterization. J Appl Pharm Sci 2018;8:14-21.

8. Suryani, Zubaydah W, Sahumena M, Adawia S, Wahyuni R. Preparation and characterization of self-nano emulsifying drug delivery system (SNEDDS) from Moringa oleifera L. and Cassia alata L. leave extracts. AIP Conf Proc 2019;2199:070011.

9. Balata G, Eassa E, Shamrool H, Zidan S, Abdo Rehab M. Selfemulsifying drug delivery systems as a tool to improve solubility and bioavailability of resveratrol. Drug Des Dev Ther 2016;10:117-28.

10. Amin N, Das B. A review on formulation and characterization of nanoemulsion. Int J Curr Pharm Res 2019;4:1-5.

11. Izham M, Nadilah M, Hussin Y, Aziz MN, Yeap SK, Rahman HS, et al. Preparation and characterization of self nano-emulsifying drug delivery system loaded with citraland its antiproliferative effect on colorectal cells in vitro. Nanomaterials 2019;9:1-18.

12. Miryala V, Kurakula M. Self-nano emulsifying drug delivery system (SNEDDS) for oral delivery of atorvastatin formulation and bioavailability studies. J Drug Deliv Ther 2015;3:131-42.

13. Wiwiek IA, Martodihardjo S, Soenardi, Jumina, Budiana I, Mustofa GM. Preparation and in-vitro characterization of the self-nano emulsifying system of C-Phenylcalix-[4]-resorcynaryl octacinnamate and C-methylcalix-[4]-resorcinaryl octabenzoate as ultraviolet absorbers. Bali Med J 2017;6:569-77.
14. Syukri Y, Fitriani H, Pandapotan H, Nugroho BH. Formulation, characterization, and stability of ibuprofen-loaded self-nano emulsifying drug delivery system (SNEDDS). Indones J Pharm 2019;30:105-13.

15. Huda N, Wahyuningsih I. Karakterisasi self-nanoemulsifying drug delivery system (SNEDDS) Minyak Buah Merah (Pandanus conoideus Lam.). J Farm Ilmu Kefarm Indones 2018;3:49-57.

16. Baloch J, Sohail MF, Sarwar HS, Kiani MH, Khan GM, Jahan S, et al. Self-nanoemulsifying drug delivery system (SNEDDS) for improved oral bioavailability of chlorpromazine: In vitro and in vivo evaluation. Medicine (Mex.) 2019;55:1-13.

17. Cherniakov I, Domb AJ, Hoffman A. Self-nano-emulsifying drug delivery systems: An update of the biopharmaceutical aspects. Expert Opin Drug Deliv 2015;12:1121-33.

18. Teng F, He M, Xu J, Che F. Effect of ultrasonication on the stability and storage of a soy protein isolate-phosphatidylcholine nanoemulsions. Nat Res 2020;10:1-9.

19. Kazi M, Shahba AA, Alrashoud S, Alwadei M, Sherif AY, Alanazi FK. Bioactive self-nanoemulsifying drug delivery systems (Bio-SNEDDS) for combined oral delivery of curcumin and piperine. Molecules 2020;25:1-24.

20. Cesar DA, Maria AG, Arantes OE, Alves DR. Production and characterization of cosmetic nanoemulsions containing Opuntia ficusindica (L.) Mill extract as moisturizing agent. Molecules 2018;20:2492-509.

21. Gurpreet K, Singh SK. Review of nanoemulsion formulation and characterization techniques. Indian J Pharm Sci 2018;80:781-9.

22. Sawant P, Kareekar P, Waghmare K. Formulation and characterization of solid lipid nanoparticles containing ginger oil for enhancement of stability. Int J Pharm Pharm Sci 2020;12:36-44.

23. Drais HK, Hussein AA. Formulation and characterization of carvedilol nanoemulsion oral liquid dosage form. Int J Pharm Pharm Sci 2015;7:209-16. 